\title{
Integrated Application of Organic and Blended Mineral Fertilizers Improves Potato Productivity and Income for Smallholder Farmers in Acidic Soils
}

\author{
Tsegaye Girma ${ }^{1,2}$, Birhanu Biazin ${ }^{3,4}$, Sheleme Beyene ${ }^{2} \&$ Berga Lemaga $^{3}$ \\ ${ }^{1}$ Southern Agricultural Research Institute, Hawassa, Ethiopia \\ ${ }^{2}$ Hawassa University, College of Agriculture, Hawassa, Ethiopia \\ ${ }^{3}$ International Potato Center (CIP), C/O, ILR, Addis Ababa, Ethiopia \\ ${ }^{4}$ International Crops Research Institute for the Semi-Arid Tropics, Addis Ababa, Ethiopia \\ Correspondence: Birhanu Biazin, International Crops Research Institute for the Semi-Arid Tropics, P.O. Box 5689, \\ Addis Ababa, Ethiopia. E-mail: B.temesgen@cgiar.org
}

Received: June 17, 2019

Accepted: August 1, 2019

Online Published: January 31, 2020

doi:10.5539/enrr.v10n1p61

URL: https://doi.org/10.5539/enrr.v10n1p61

\begin{abstract}
Potato (Solanum tuberosum) is the world's third most important food crop. However, potato productivity is very low in acidic soils that cover about $50 \%$ of the arable land in the world. Therefore, the aim of this study was to evaluate the effect of sole and integrated farmyard manure (FYM) and different types of mineral fertilizers on yield, yield components and economic returns of potato in acidic soils of Ethiopia. Six treatments: 1) Control (without fertilizer), 2) sole application of the recommended NP (RNP) fertilizer (11 kg/ha N and $40 \mathrm{~kg} / \mathrm{ha} \mathrm{P}$ ), 3) sole FYM (28.8 t/ha FYM), 4) half dose of recommended NP fertilizer and half dose of the FYM, 5) blended fertilizer formulated as $17.3 \mathrm{~kg} \mathrm{~N}, 34.7 \mathrm{~kg} \mathrm{P}_{2} \mathrm{O}_{5}, 7.41 \mathrm{~kg} \mathrm{~S}, 2.23 \mathrm{~kg} \mathrm{Zn}, 0.3 \mathrm{~kg} \mathrm{~B}+100 \mathrm{~kg} / \mathrm{ha} \mathrm{K}$ ), and 6) half blended and half FYM, were arranged in a randomized complete block design. The results revealed that potato plants amended with sole blended fertilizer, and integrated FYM, and mineral fertilizers doubled fresh tuber yield as compared to the control. The RNP fertilizer gave the lowest $(\alpha<0.05)$ marketable potato yield of all the fertilizer treatments. Applications of sole blended or integrated FYM and mineral fertilizers resulted in the highest net benefit with acceptable marginal rate of return. Integrated use of FYM and mineral fertilizers is crucial for improved and sustained smallholder potato production in acidic soils. Further studies are required to examine the long-term effects of blended fertilizers on soil properties.
\end{abstract}

Keywords: Farmyard Manure, Blended Fertilizer, Yield Components, Ethiopia

\section{Introduction}

Potato (Solanum tuberosum) is the world's third most important food crop after wheat and rice (Birch et al., 2012). The mean world potato yield was estimated at $19.5 \mathrm{t} / \mathrm{ha}$ in 2016 (FAOSTAT, 2016). Billions of people across the world eat it on a regular basis. Although the crop was mainly produced in Europe and North America, it has become an increasingly important food security crop in many developing countries (Birch et al., 2012; Bradshaw \& Bonierbale, 2010). For instance, in Ethiopia the area under potato increased from 62,000 ha to 296,578 ha and production increased from 500,000 tons to 3.6 million tons from 2006 to 2016, respectively (CSA, 2006; CSA, 2016; FAOSTAT, 2016). Potato is a nutritious, high-value, short production cycle crop, which is important for food security and income generation in humid and dry sub-humid agro-ecologies across Africa (Birch et al., 2012; Bradshaw \& Bonierbale, 2010; Hirpa et al., 2016).

While acidic soils cover about $30 \%$ of the world's total land area and more than $50 \%$ of the world's potential arable lands (Guo et al., 2010), potato is one of the major crops with ever increasing coverage in acidic soil (von Uexku 11 \& Mutert, 1995). However, soil acidity is one of the threatening factors causing low soil fertility and hence reduced crop yields due to aluminum toxicity and phosphorus deficiency (Liu et al., 2008; Zheng, 2010). In Acidic soils, large amounts of $\mathrm{P}$ applied as fertilizer could enter into the immobile pools through precipitation reaction with highly reactive $\mathrm{Al}^{3+}$ and $\mathrm{Fe}^{3+}$ (Hao et al., 2002; Haynes \& Mokolobate, 2001). Low inherent soil fertility associated with soil acidity coupled with inadequate use of organic and inorganic fertilizers by smallholder 
farmers has caused low potato productivity in Africa (ATA, 2014; Druilhe \& Barreiro-Hurlé, 2012; Ephrem, 2015; Kefyalew, 2010; Kinyua et al., 2001; Lemaga et al., 2001; Mesfin, 2009; Olanya et al., 2001).

Although fertilizer recommendations based on soil fertility assessments are not common in Africa, the Ethiopian Agricultural Transformation agency (ATA) through its Ethiopian Soil Information System (EthioSIS) project has recently made a national assessment on soil fertility status at district levels to give evidence-based specific fertilizer recommendations (ATA, 2016). For this purpose, EthioSIS gathered and analyzed soil samples from more than 18,000 sites. Accordingly, new blended fertilizers that have nitrogen, phosphorus and Sulphur as basic nutrients and blending them with minor nutrients such as $\mathrm{Zn}, \mathrm{Cu}$ and $\mathrm{B}$ were recommended depending on their deficiencies in the soils of different districts in the country. However, the responses of various crops in terms of yield and economic performances to blended fertilizers have not yet been studied. On the other hand, although smallholder farmers in SSA use traditional soil fertility improvement methods such as manuring, intercropping, compost, crop residue and fallowing to a lesser extent (Place et al., 2003), integrated application of organic and mineral fertilizers is less common. Therefore, this study was initiated to evaluate the effects of sole and integrated applications of mineral fertilizers, either the newly blended or the RNP fertilizers, and farmyard manure on yield, yield components and economic return of potato by smallholder farmers in acid soils of the Ethiopian highlands.

\section{Materials and Methods}

\subsection{Description of the Study Area}

This study was carried out in Arbegona district of southern Ethiopia. The study area lies between 6 $34^{\prime} 19^{\prime \prime}-$ $6^{\circ} 47^{\prime} 54^{\prime \prime} \mathrm{N}$ latitude and 38 35'60"-38 53'36"E longitude (Figure 1). The experimental site is located at about 78 $\mathrm{km}$ southeast of Hawassa city, the capital of the Southern region, at an elevation of 2,521 meters above sea level. The study area has a mean annual rainfall of $1400 \mathrm{~mm}$ and a mean annual reference evapo-transpiration of 1123 mm (Mekasha et al., 2015). The study area has predominantly Nitosols (Paul, 2016). Major crops grown in the study area include enset (Enset ventricosum), potato (Solanum tuberosum), maize (Zea mays), wheat (Triticum aestivum), field pea (Pisum sativum), cabbage (Brassica oleracea), carrot (Daucus carota), Ethiopian cabbage (Brassica carinata), onion (Allium cepa.) and Garlic (Allium sativum). The average livestock holding of the farm households in the study area was reported to be 17 , out of which cattle and sheep shared about 47 and $41 \%$, respectively (Mekasha et al., 2015).

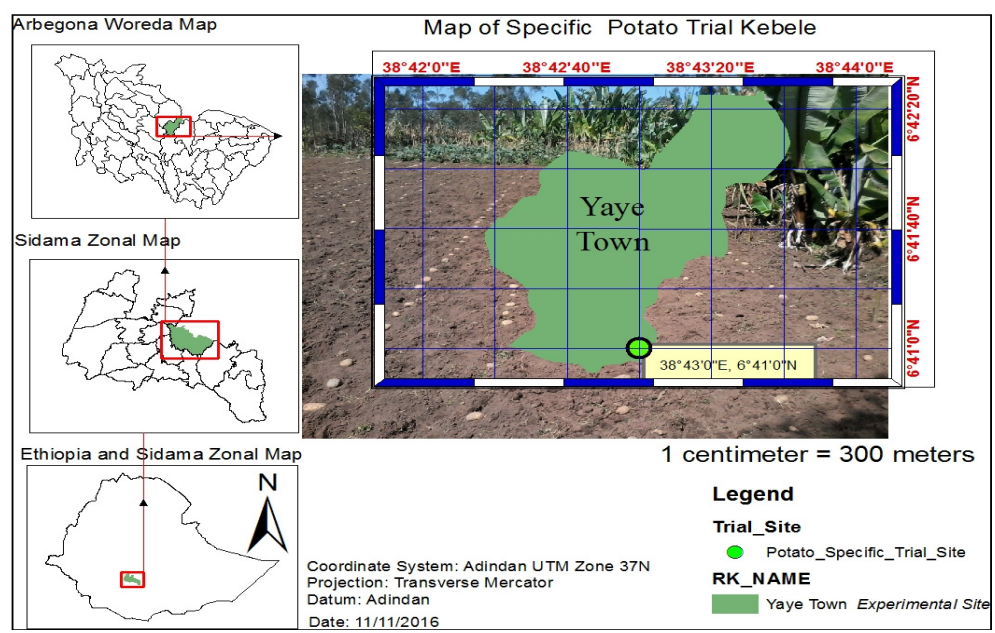

Figure 1. Geographical location of the study site at Arbegona district (locally known as woreda) in the southern Ethiopian highlands

\subsection{Experimental Design and Treatments}

The field experiment was laid out in a Randomized Complete Block Design (RCBD) with six treatments (Table 1). Each treatment was replicated three times and the experiment was conducted for two consecutive growing seasons. The first experiment was undertaken from December 19/2015 to April 15/2016, while the second from August 24/2016 to December 22/2016. During rain shortage, supplemental surface irrigation was applied evenly to all treatments. A blended fertilizer formulation composed of nitrogen, phosphorus, sulfur, zinc, boron and 
potassium (NPSZnB+K) was used as it was recommended for the highland acidic soils which have problems of phosphorus fixation and deficiency of micro-nutrients like zinc and boron (ATA, 2016). This blended fertilizer contained $17.3,34.7,7.4,2.2$ and $0.3 \%$ of $\mathrm{N}, \mathrm{P}_{2} \mathrm{O}_{5}, \mathrm{~S}, \mathrm{Zn}$, and $\mathrm{B}$, respectively.

The amount of decomposed FYM used in the experiment was determined based on the nutrient contents of the widely available dry FYM from cattle in the study area. Therefore, the amount of FYM was estimated based on concentrations of major nutrients (Table 1). The concentrations of N, P and K in the FYM were high substantiating the findings of Hazelton and Murphy (2007) and Landon (2013). The FYM had 28.8\% moisture content on average during application, and hence this was used as a correction factor ( $\mathrm{mcf}$ ) for the calculations of nitrogen, phosphorus and potassium contents.

For the field experiments, clean seed potato of the variety Belete was planted at a spacing of 75 and $30 \mathrm{~cm}$, between rows and plants, respectively. The plot size was $4 \mathrm{~m}$ wide and $3 \mathrm{~m}$ long with $1 \mathrm{~m}$ spacing. The FYM and inorganic fertilizer were applied on the sides of seed potatoes on ridges and covered with soil to avoid contact. All the recommended rates of $\mathrm{P}, \mathrm{K}, \mathrm{S}, \mathrm{Zn}$ and $\mathrm{B}$ according to the different treatments were applied at planting, whereas $\mathrm{N}$ was applied in split: half at planting and the remaining half at about 35 days after planting.

Table 1. Different sole and integrated organic and inorganic soil amendment techniques that were tested for their effects on potato production by smallholder farmers at Arbegona in the southern highlands of Ethiopia

\begin{tabular}{|c|c|c|c|c|c|c|c|}
\hline \multirow{2}{*}{ No. } & \multirow{2}{*}{ Type of treatment } & \multicolumn{6}{|c|}{ Applied Nutrients $\left(\mathrm{kg} \mathrm{ha}^{-1}\right)$ from different fertilizer sources } \\
\hline & & $\mathrm{N}$ & $\mathrm{P}$ & $\mathrm{S}$ & $\mathrm{Zn}$ & $\mathrm{B}$ & $\mathrm{K}$ \\
\hline 1 & Control (without any fertilizer) & 0 & 0 & 0 & 0 & 0 & 0 \\
\hline 2 & Recommended NP (RNP) & 111 & 40 & 0 & 0 & 0 & 0 \\
\hline 3 & Combined RNP and FYM (each sharing half of the rate) & 111 & 38.5 & * & * & * & 27.7 \\
\hline 4 & Sole FYM & $111^{1}$ & $36.9^{2}$ & * & * & * & 55.4 \\
\hline 5 & Combined Blended and FYM (each sharing half of the rate) & 111 & 38.5 & 9.78 & 2.49 & 0.39 & 77.7 \\
\hline 6 & Sole Blended & 111 & 40 & 19.56 & 4.99 & 0.79 & 100 \\
\hline
\end{tabular}

$R N P=$ recommended nitrogen and phosphorus fertilizer (DAP and Urea); FYM = Farmyard manure; Blended fertilizer $=$ formulated fertilizer from NPSZnB $+K ; N=$ Nitrogen, $P=$ Phosphorous, $K=$ Potassium, $S=$ Sulphur, $Z n=$ Zinc, and B= Boron;

*The concentrations of $S, Z n$ and $B$ in the FYM were not analyzed.

${ }^{1} \mathrm{~N}$ from FYM calculated based on the recommended dose (111 kg of Nitrogen) considering only $\mathrm{N}(50 \%)$ availability (Kirsten, 2014) from (222 kg N in $28.8 \mathrm{t} \mathrm{FYM} \mathrm{ha}^{-1}$ ). Manure $\mathrm{P}$ and $\mathrm{K}$ occur mostly in a soluble form similar to the PK in fertilizer (Mengel \& Kirkby, 1987; Kirsten, 2014).

\subsection{Data Collection and Analysis}

\subsubsection{Soil and Plant Samples Collection and Preparation}

Before the start of the field experiment, twenty surface soil samples $(0-20 \mathrm{~cm})$ were taken randomly from the experimental field. The soil samples were composited and prepared for analyses of the soil physico-chemical properties (Table 2) at the soil laboratory of Hawassa University.

During the experimental periods, data on plant height and numbers of stems per hill were recorded. Plant heights were determined at $50 \%$ flowering, approximately at about 9 weeks after planting by measuring the length from the base of the plants to the apex. Number of tubers per hill, foliage weight, tuber weights per plant, marketable and unmarketable tubers were determined at harvesting. The characteristics of unmarketable tubers were determined as explained by Fahmy et al. (2008) and Kavvadias et al. (2012). For potatoes and similar root crops, the yield components are number of stems per plant, number of tubers per plant and average tuber weight (Mengel \& Kirkby, 1987).

Uniform small pieces of fresh tubers were taken, and tuber dry weights were determined after drying in an oven at $65^{\circ} \mathrm{C}$ to a constant weight. Five-hundred-gram fresh weight was used for determination of dry matter content. The harvest index (HI) was computed by dividing the harvestable yield by the total biomass, both on a dry weight basis.

\subsubsection{Soil Analysis}


Soil parameters including particle size distribution, $\mathrm{pH}$, organic carbon, total nitrogen, available $\mathrm{P}$ and $\mathrm{K}$ were analyzed following standard laboratory procedures. The composite soil samples were passed through $2 \mathrm{~mm}$ sieve for analyses, except for organic carbon and total $\mathrm{N}$ where a $0.5 \mathrm{~mm}$ sieve was used. A hydrometer method was used to determine the particle-size distribution (Gee \& Bauder, 1986). The soil pH was measured using a pH meter in supernatant suspension of a 1:2.5 soil to water mixture as outlined by Sahlemedhin and Taye, (2000). Total nitrogen (TN) was analyzed by wet-oxidation procedure of the Kjeldahal method and available $\mathrm{P}$ and $\mathrm{K}$ were determined by Bray II method using spectrophotometer and Morgan's extracting solution methods, respectively (Motsara \& Roy, 2008).

Soil organic carbon (OC) was determined following the wet oxidation method (Walkley \& Black, 1934). Farmyard manure was subjected to $\mathrm{pH}, \mathrm{OC}, \mathrm{TN}$ and available $\mathrm{P}$ and $\mathrm{K}$ analyses. All the soil analyses were done at the soil laboratory of Hawassa University in southern Ethiopia.

Table 2. Selected chemical properties of the surface soil and farmyard manure used in the experiment at Arbegona in the southern highlands of Ethiopia

\begin{tabular}{llllll}
\hline \multirow{2}{*}{ Material } & \multicolumn{5}{c}{ Chemical properties } \\
& $\mathrm{pH}$ & $\mathrm{OC}(\%)$ & $\mathrm{TN}(\%)$ & Ava. P $\left(\mathrm{mg} \mathrm{kg}^{-1}\right)$ & Ava. K $\left(\mathrm{cmol}^{(+)} \mathrm{kg}^{-1}\right)$ \\
\hline Surface soil (0-20 cm) & 4.81 & 2.64 & 0.21 & 7.43 & 0.48 \\
FYM & 7.1 & 11.38 & 1.082 & 1831 & 6.94 \\
\hline
\end{tabular}

\subsection{Economic Analyses}

Partial budget and marginal rate of return (MRR) analyses were done to determine the economic benefits and make a rational choice among the studied soil amendments for potato production in acidic soils of Ethiopian highland farming system using the procedure developed by CIMMYT (1988). Partial budget analysis evaluates consequences of changes in farm methods that affect only a part rather than the whole farm. It is used as a planning tool to estimate the effect of on-farm profit to a particular change (Berhanu et al., 2012). Partial budget was computed at $10 \%$ yield adjusted, multiplied by the mean local farmgate price of $\$ 30.16$ USD per $100 \mathrm{~kg}$ of potato at the time of harvest. A dominance analysis was carried out by first listing the treatments. A dominated treatment is any treatment that has net benefits that are less than those of a treatment with lower variable costs (CIMMYT, 1988).

\subsection{Statistical Analysis}

Data collected on plant parameters were subjected to descriptive statistics, analysis of variance (ANOVA) and correlation analyses using SAS software (version 9.0). Mean separations of the parameters in response to different treatments were made using the Least Significant Differences (LSD) at $\mathrm{P}=0.05$ level of significance. Pearsoncorrelation and path coefficients were also analyzed (SAS, 1997).

\section{Results}

\subsection{Physicochemical Properties of the Experimental Soil}

The experimental soil was loamy in textural class with 43,39 and $18 \%$ sand, silt and clay particles, respectively. It is very strongly acidic in reaction and the organic carbon content of the soil could be rated as very high (Table 2). On the other hand, the total $\mathrm{N}$ and available $\mathrm{K}$ contents of the soil were medium whereas the available $\mathrm{P}$ was low in accordance with ratings by Landon (2013). The considerably high available P and K values in the FYM (Table 2) revealed that there is ample opportunity to improve soil fertility through applications of FYM.

\subsection{Effect of Soil Amendments on Yield and Yield Components of Potato}

Fresh shoot biomass, marketable and unmarketable tuber yields were significantly $(\mathrm{P}<0.05)$ affected by soil amendments (Table 3). The lowest values of fresh shoot biomass, and marketable and unmarketable tuber yields were obtained from the control plots that were not treated with fertilizers (Table 4). The application of the recommended amount of NP mineral fertilizer did not significantly $(\mathrm{P}=0.05)$ increase fresh shoot biomass in both seasons. The highest value of shoot biomass was obtained from combined use of FYM and mineral fertilizers (recommended NP or blended) or sole application of a blended fertilizer. All the different soil amendment 
techniques have significantly $(\mathrm{P}<0.05)$ increased marketable tuber yield. The highest fresh tuber yield was obtained from combined use of FYM and mineral fertilizers (recommended NP or blended) or sole application of a blended fertilizer.

Plant height and number of tubers per plant were significantly $(\mathrm{P} \leq 0.05)$ different among the different soil amendments during both experimental seasons (Table 3). The lowest plant height was recorded in the control experiment where there was no application of chemical or organic fertilizers. Combined applications of FYM with blended fertilizer, and FYM with RNP resulted in the highest number of tubers per plant.

Table 3. Effect of sole and integrated organic and inorganic fertilizers on yield and yield components of potato at Arbegona in the southern highlands of Ethiopia

\begin{tabular}{|c|c|c|c|c|c|c|c|c|}
\hline Season & Treatment & $\begin{array}{l}\text { Shoot } \\
\text { Biomass } \\
\text { yield (t/ha) }\end{array}$ & $\begin{array}{l}\text { Marketable } \\
\text { tuber yield } \\
\text { (t/ha) }\end{array}$ & $\begin{array}{l}\text { Unmarket- } \\
\text { able tuber } \\
\text { Yield (t/ha) }\end{array}$ & $\begin{array}{l}\text { Tuber Dry } \\
\text { Matter (\%) }\end{array}$ & $\begin{array}{l}\text { Harvest } \\
\text { Index (HI) } \\
(\%)\end{array}$ & $\begin{array}{l}\text { Plant } \\
\text { Height (PH) } \\
\text { in cm }\end{array}$ & $\begin{array}{l}\text { Tuber No/ } \\
\text { Hill (TNH) }\end{array}$ \\
\hline \multirow{6}{*}{$\begin{array}{l}\text { First } \\
\text { (Dec. } 19 \\
2015- \\
\text { April } 15 \\
2016)\end{array}$} & Control & $15.4\left( \pm 0.4^{\mathrm{d}}\right)$ & $25.6\left( \pm 1.4^{\mathrm{d}}\right)$ & $2.4\left( \pm 0.1^{c}\right)$ & $20.8\left( \pm 0.2^{\text {ba }}\right)$ & $64.4\left( \pm 0.6^{\mathrm{d}}\right)$ & $55.6\left( \pm 1.4^{\mathrm{c}}\right)$ & $4.9\left( \pm 0.3^{\mathrm{d}}\right)$ \\
\hline & RNP & $18.2\left( \pm 1.6^{\mathrm{dc}}\right)$ & $38.2\left( \pm 2.9^{c}\right)$ & $2.1\left( \pm 0.1^{\mathrm{c}}\right)$ & $20.5\left( \pm 0.1^{b}\right)$ & $69.0\left( \pm 0.9^{c}\right)$ & $66.9\left( \pm 1.6^{\text {ba }}\right)$ & $6.2\left( \pm 0.2^{\mathrm{dc}}\right)$ \\
\hline & $\begin{array}{l}\text { RNP } \quad+ \\
\text { FYM }\end{array}$ & $24.1\left( \pm 0.9^{\mathrm{a}}\right)$ & $54.8\left( \pm 3.5^{\mathrm{a}}\right)$ & $3.2\left( \pm 0.1^{\mathrm{ba}}\right)$ & $21.2\left( \pm 0.1^{\mathrm{a}}\right)$ & $70.6\left( \pm 0.5^{\mathrm{cb}}\right)$ & $64.7\left( \pm 2.0^{b}\right)$ & $8.9\left( \pm 1.0^{\mathrm{a}}\right)$ \\
\hline & FYM & $19.1\left( \pm 0.7^{\mathrm{cb}}\right)$ & $45.6\left( \pm 2.5^{\mathrm{cb}}\right)$ & $3.4\left( \pm 0.1^{\mathrm{ba}}\right)$ & $20.7\left( \pm 0.2^{\mathrm{ba}}\right)$ & $71.9\left( \pm 1.1^{\mathrm{ba}}\right)$ & $65.4\left( \pm 1.6^{\mathrm{a}}\right)$ & $7.6\left( \pm 0.1^{\mathrm{ba}}\right)$ \\
\hline & $\begin{array}{l}\text { Blended + } \\
\text { FYM }\end{array}$ & $21.4\left( \pm 0.8^{\mathrm{ba}}\right)$ & $57.7\left( \pm 2.2^{\mathrm{a}}\right)$ & $3.5\left( \pm 0.2^{\mathrm{a}}\right)$ & $21.2\left( \pm 0.2^{\mathrm{a}}\right)$ & $74.1\left( \pm 1.6^{a}\right)$ & $70.5\left( \pm 1.3^{\mathrm{a}}\right)$ & $8.5\left( \pm 0.4^{\mathrm{a}}\right)$ \\
\hline & Blended & $22.4\left( \pm 0.6^{\mathrm{a}}\right)$ & $53.4\left( \pm 2.4^{\mathrm{ba}}\right)$ & $3.1\left( \pm 0.1^{b}\right)$ & $21.1\left( \pm 0.04^{\mathrm{a}}\right)$ & $71.6\left( \pm 0.4^{b}\right)$ & $65.3\left( \pm 1.4^{\mathrm{b}}\right)$ & $6.9\left( \pm 0.4^{\mathrm{cb}}\right)$ \\
\hline \multirow{10}{*}{$\begin{array}{l}\text { Second } \\
\text { (Aug. } 24 \\
\text { 2016- } \\
\text { Dec. } 22 \\
2016 \text { ) }\end{array}$} & $\begin{array}{l}\text { Season } 1 \\
\text { Mean } \pm \text { SE }\end{array}$ & $20.1( \pm 1)$ & $45.9( \pm 2.8)$ & $3.0( \pm 0.1)$ & $20.9( \pm 0.2)$ & $70.3( \pm 0.7)$ & $62( \pm 1.5)$ & $7.1( \pm 1.4)$ \\
\hline & $\operatorname{LSD}(0.05)$ & 3.1 & 8.7 & 0.3 & 0.5 & 2.2 & 4.8 & 1.4 \\
\hline & Control & $13.6\left( \pm 0.7^{\mathrm{c}}\right)$ & $21.9\left( \pm 2.2^{\mathrm{d}}\right)$ & $2.6\left( \pm 0.3^{b}\right)$ & $20.8\left( \pm 0.2^{\mathrm{ba}}\right)$ & $59.8\left( \pm 3.0^{\mathrm{d}}\right)$ & $55.7\left( \pm 1.5^{\mathrm{b}}\right.$ & $4.9\left( \pm 0.3^{c}\right)$ \\
\hline & RNP & $15.6\left( \pm 1.4^{\mathrm{cb}}\right)$ & $35.9\left( \pm 4.9^{\mathrm{c}}\right)$ & $4.6\left( \pm 0.7^{\mathrm{a}}\right)$ & $20.6\left( \pm 0.0^{b}\right)$ & $66.3\left( \pm 2.3^{\mathrm{cb}}\right)$ & $67.8\left( \pm 1.7^{\mathrm{a}}\right)$ & $5.7\left( \pm 0.1^{\mathrm{cb}}\right)$ \\
\hline & $\begin{array}{l}\text { RNP } \quad+ \\
\text { FYM }\end{array}$ & $21.5\left( \pm 2.2^{\mathrm{a}}\right)$ & $51.8\left( \pm 4.5^{\mathrm{ba}}\right)$ & $5.0\left( \pm 0.7^{\mathrm{a}}\right)$ & $21.1\left( \pm 0.1^{\mathrm{a}}\right)$ & $64.7\left( \pm 2.5^{\mathrm{c}}\right)$ & $64.4\left( \pm 4.1^{\mathrm{a}}\right)$ & $8.7\left( \pm 1.2^{\mathrm{a}}\right)$ \\
\hline & FYM & $17.2\left( \pm 1.1^{\mathrm{cba}}\right)$ & $40.8\left( \pm 4.0^{\mathrm{cb}}\right)$ & $5.4\left( \pm 0.6^{a}\right)$ & $20.7\left( \pm 0.2^{b}\right)$ & $64.6\left( \pm 2.6^{c}\right)$ & $65.3\left( \pm 3.8^{\mathrm{a}}\right)$ & $7.4\left( \pm 0.4^{\mathrm{ba}}\right)$ \\
\hline & $\begin{array}{l}\text { Blended + } \\
\text { FYM }\end{array}$ & $18.1\left( \pm 1.3^{\mathrm{ba}}\right)$ & $55.1\left( \pm 3.0^{\mathrm{a}}\right)$ & $5.3\left( \pm 0.2^{\mathrm{a}}\right)$ & $21.2( \pm 0.2)$ & $73.3\left( \pm 0.4^{\mathrm{a}}\right)$ & $70.3\left( \pm 2.4^{\mathrm{a}}\right)$ & $8.8\left( \pm 0.3^{\mathrm{a}}\right)$ \\
\hline & Blended & $18.7\left( \pm 1.1^{\mathrm{ba}}\right)$ & $48.2\left( \pm 2.7^{\mathrm{ba}}\right)$ & $5.8\left( \pm 0.2^{\mathrm{a}}\right)$ & $21.2\left( \pm 0.2^{\mathrm{a}}\right)$ & $68.1\left( \pm 1.3^{\text {ba }}\right)$ & $66.1\left( \pm 2.6^{\mathrm{a}}\right)$ & $7.6\left( \pm 0.4^{\mathrm{a}}\right)$ \\
\hline & $\begin{array}{l}\text { Season } 2 \\
\text { Mean } \pm \text { SE }\end{array}$ & $17.5( \pm 1.4$ & $42.3( \pm 3.7$ & $4.8( \pm 0.5$ & $20.9( \pm 0.1$ & $66.1( \pm 0.9)$ & $64.9( \pm 2.5)$ & $7.2( \pm 0.6)$ \\
\hline & $L S D(0.05)$ & 4.4 & 11.6 & 1.6 & 0.5 & 2.8 & 8 & 1.8 \\
\hline \multirow{5}{*}{$\begin{array}{l}\text { Mean of } \\
\text { the two } \\
\text { seasons }\end{array}$} & Season Eval & tion & & & & & & \\
\hline & $\begin{array}{l}\text { Season } 1 \\
\operatorname{Mean} \pm \mathrm{SE}\end{array}$ & $20.1\left( \pm 0.5^{\mathrm{a}}\right)$ & $45.9( \pm 1.3)$ & $3.0\left( \pm 0.2^{b}\right)$ & $20.9( \pm 0.1)$ & $70.3\left( \pm 0.3^{\mathrm{a}}\right)$ & $64.7( \pm 2.1)$ & $7.2( \pm 0.5)$ \\
\hline & $\begin{array}{l}\text { Season } 2 \\
\text { Mean } \pm \text { SE }\end{array}$ & $17.5\left( \pm 0.5^{b}\right.$ & $42.3( \pm 1.3$ & $4.8\left( \pm 0.2^{\mathrm{a}}\right)$ & $20.9( \pm 0.1)$ & $66.1\left( \pm 0.3^{b}\right)$ & $64.9( \pm 2.1)$ & $7.2( \pm 0.5)$ \\
\hline & $\begin{array}{l}\text { Combined } \\
\text { Mean } \pm \text { SE }\end{array}$ & $18.8( \pm 0.5$ & $44.1( \pm 1.3$ & $4.9( \pm 0.2$ & $20.9( \pm 0.1$ & $68.2( \pm 0.3$ & $64.8( \pm 2.1)$ & $7.2( \pm 0.5)$ \\
\hline & $\operatorname{LSD}(0.05)$ & 1.5 & 3.9 & 0.4 & 0.5 & 1 & 2.5 & 0.6 \\
\hline
\end{tabular}

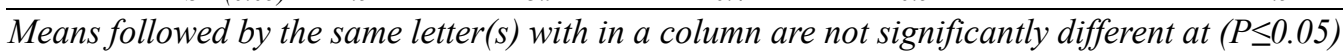

$R N P=$ recommended nitrogen and phosphorus fertilizer (DAP and UREA), FYM = Farmyard manure, Blended $=$ formulated fertilizer from $\mathrm{NPSZnB}+K$, and $S E=$ Standard Error in brackets

\subsection{Effect of Different Soil Amendments on the Economic Return of Potato}

The result of the partial budget analysis revealed that all soil amendments resulted in higher net benefits than the control with respect to the acceptable MRR (Figure 2; Table 4). The dominancy analyses indicated that sole application of FYM could be less profitable due to the increased cost incurred for transportation. The application 
of combined FYM and blended fertilizer resulted in the highest net benefit followed by combined FYM and RNP fertilizers (Figure 2 and Table 4). For every \$1.00 invested in application of FYM combined with blended fertilizer, farmers can expect to recover $\$ 1.00$, and obtain an additional $\$ 31.06 \mathrm{ha}^{-1}$ averaged over two seasons. All the studied soil amendments, except for application of sole FYM, could be economically feasible for potato producing farmers in the study area. The cost of transporting FYM from the homesteads where farmers commonly keep their livestock to the farm plots is high due to its bulkiness.

Table 4. Partial budget and marginal rate of return analyses of potato as influenced by soil amendments at Arbegona in the southern highlands of Ethiopia

\begin{tabular}{|c|c|c|c|c|c|}
\hline Season & Treatments & $\begin{array}{l}10 \% \text { yield } \\
\text { adjusted } \\
(\mathrm{t} / \mathrm{ha})\end{array}$ & $\begin{array}{l}\text { Total Cost that vary } \\
\left(\text { TCV) ( }{ }^{\$} \text { USA Dollar ha' }{ }^{-1}\right)\end{array}$ & $\begin{array}{l}\text { Net Benefits (NB) }\left({ }^{\mathrm{S}} \mathrm{USA}\right. \\
\text { Dollar tubers sold }\left(\mathrm{t} \mathrm{ha}^{-1}\right)\end{array}$ & $\begin{array}{l}\text { Marginal Rate of } \\
\left.\text { Return (MRR \% } \%^{1}\right)\end{array}$ \\
\hline \multirow{7}{*}{$\begin{array}{l}\text { First } \\
\text { (Dec. } 19 \\
\text { 2015-April } \\
15 \text { 2016) }\end{array}$} & Control & 25.3 & 0.00 & 7644.36 & \\
\hline & $\begin{array}{l}\text { Recommend } \\
\text { NP(RNP) }\end{array}$ & 37.8 & 208.54 & 11198.28 & 1704 \\
\hline & Blended & 52.9 & 261.41 & 14457.66 & 6164 \\
\hline & $\begin{array}{l}\text { Half RNP and } \\
\text { FYM }\end{array}$ & 54.3 & 442.55 & 14662.41 & 113 \\
\hline & $\begin{array}{l}\text { Half Blended } \\
\text { and FYM }\end{array}$ & 57.1 & 468.99 & 15435.33 & 2924 \\
\hline & FYM & 45.1 & 676.57 & $11892.53^{\mathrm{D}}$ & \\
\hline & Control & 19.71 & 0.00 & 5844.66 & \\
\hline \multirow{5}{*}{$\begin{array}{l}\text { Second } \\
\text { (Aug. } 24 \\
\text { 2016-Dec. } \\
22 \text { 2016) }\end{array}$} & $\begin{array}{l}\text { Recommend } \\
\text { NP(RNP) }\end{array}$ & 32.31 & 205.02 & 9375.96 & 1722 \\
\hline & Blended & 43.38 & 257.00 & 12606.52 & 6206 \\
\hline & $\begin{array}{l}\text { Half RNP and } \\
\text { FYM }\end{array}$ & 46.62 & 435.08 & 13389.28 & 440 \\
\hline & $\begin{array}{l}\text { Half Blended } \\
\text { and FYM }\end{array}$ & 49.59 & 461.07 & 14243.98 & 3287 \\
\hline & FYM & 36.72 & 665.15 & $10223.54^{\mathrm{D}}$ & \\
\hline
\end{tabular}

\$The exchange rate of 1 \$ (Dollar) was 21.55 Ethiopian Birr for first season (April, 2016) and 21.92 Ethiopian Birr for the second season (December 2016) trials, respectively ${ }^{D}$ indicates the dominated treatments

$R N P=$ recommended nitrogen and phosphorus fertilizer (DAP and UREA); FYM = Farmyard manure; Blended $=$ formulated fertilizer from $\mathrm{NPSZnB}+K$.

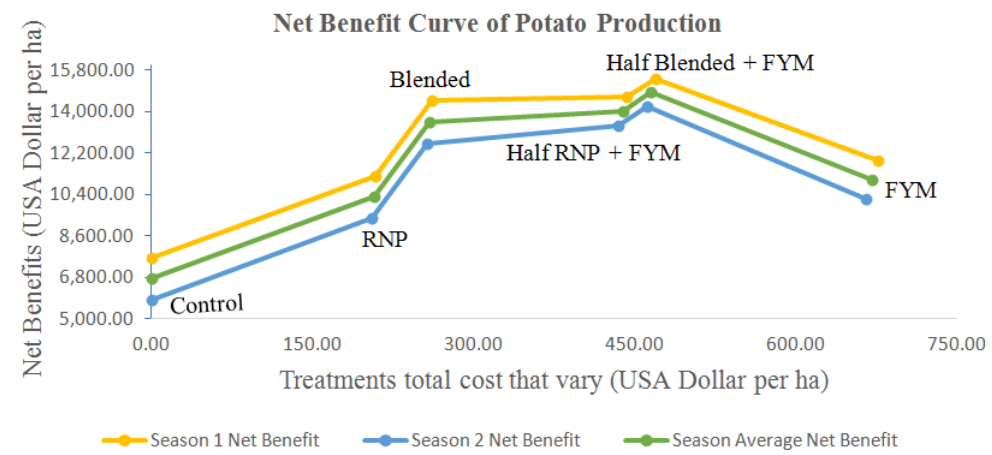

$R N P=$ recommended nitrogen and phosphorus fertilizer (DAP and UREA), FYM = Farmyard manure, and Blended $=$ formulated fertilizer from $\mathrm{NPSZnB}+K$

Figure 2. Net benefit curve (season average) of potato as influenced by soil amendments at Arbegona in Southern Ethiopia

\section{Discussions}


The strongly acidic soils of the study area might have significantly contributed to $\mathrm{P}$ deficiency for potato production. In acidic soils, a substantial percentage of the cation exchange capacity is satisfied by Aluminium ions creating significant Al saturation (Haynes \& Mokolobat, 2001). Aluminum oxides have high tendency to adsorb $\mathrm{P}$ onto their surfaces and will trigger $\mathrm{P}$ fixation. The available $\mathrm{P}$ was low in accordance with ratings by Landon (2013). Alemayehu et al. (2017) reported the abundance of $\mathrm{Al}+\mathrm{Fe}-\mathrm{P}$ as a result of variable $\mathrm{Al}$ and $\mathrm{Fe}$ contents and their reactions with soil $\mathrm{P}$ in soils of Hagereselam, close to the study site. The organic carbon content of the soil could be rated as very high in accordance with Hazelton and Murphy (2007). The high OC content of the soil could be attributed to low decomposition rate in very strong acidity as it affects activities of microorganisms (Havlin et al., 1999; Mengle \& Kirkby, 1987; FAO, 2015). The highly available P and K values in the FYM (Table 3) revealed that there is ample opportunity to improve soil fertility through sufficient applications of FYM. However, only 18 and 26\% of potato farmers in Africa applied FYM to maintain soil fertility (Gildemacher et al., 2009).

Averaged over seasons, application of either blended fertilizer alone or integrated FYM and mineral fertilizers resulted in a $100 \%$ increment in marketable tuber yields as compared to the control. The significant increases in tuber yields from the use of FYM alone or combined FYM and mineral fertilizers could be attributed either to the release of limiting essential nutrients from FYM or to the effect of FYM in reducing $\mathrm{P}$ adsorption in acidic soils. Manure can change soil pH and improve soil P availability (Shen et al., 2011). Haynes and Mokolobates (2001) stated that organic residues could be used as a strategic tool to reduce the rates of lime and fertilizer P required for optimum crop production on acidic, P-fixing soils.

Tuber dry matter percentage and harvest index of potato differed significantly $(\mathrm{P} \leq 0.05)$ between the different fertilizer treatments (Table 3). The results agree with a previous study by Ezzat et al. (2011). When the $\mathrm{N}$ level and $\mathrm{K}$ fertilization increased, the dry matter percentage decreased, which in turn reduced tuber dry matter percentage by increasing tuber water content (Ezzat et al., 2011). Tuber dry matter content and HI increased by 15 and $16 \%$ due to application of FYM alone and integrated FYM and blended fertilizer over the control, respectively. This substantiates the findings of Ahmad et al. (2014) who reported that HI increased by 5.5 to $14 \%$ due to applications of different levels of sole and combined applications of FYM and inorganic $\mathrm{K}$ fertilizer.

The current results in tuber numbers per hill are in line with the findings of El-Khider (2003). Plant height was $26.5 \%$ higher in plots treated with half FYM and half blended fertilizers as compared to the control. Das et al. (2015) reported a similar response of potato height on a different variety. The significantly higher effects of combined organic and mineral fertilizers on yield components of potato might be attributed to their complementary effects, whereby the inorganic fertilizers enable the immediate availability of nutrients while the FYM supply nutrients slowly throughout the growing period and improve the soil properties such as soil porosity and reduced soil acidity (Fahmy et al., 2008).

A shortage of one of the essential nutrients can limit crop yields (Lones \& Jacobsen, 2001). Under limited soil nutrient conditions, the required nutrients may come from soil reserves, added fertilizer or manure, and crop residues (Kirsten, 2014). Due to the low decomposition rate of organic matter such as FYM, nutrients could be available gradually, thus reducing the risks of immediate loss by leaching and erosion, particularly in high rainfall areas (Mengel \& Kirkby, 1987; Kirsten, 2014). Inorganic fertilizers such as DAP, ammonium nitrate and ammonium are considered as acid forming fertilizers (Sommer et al., 2004; Schroder et al., 2011). Thus, integrated use of organic and mineral fertilizers could have a positive influence on reducing soil acidity. The FYM likely enhances mineralization of organically bound $\mathrm{P}$ and also desorption of $\mathrm{Al}+\mathrm{Fe}-\mathrm{P}$ in strongly acidic soils by increasing phosphatase activity and microbial biomass in the soil (Takeda et al., 2009).

\section{Conclusion}

The yield and yield components of potato were significantly affected by different types of fertilizers. Yet, there were differences in yield response to different types of fertilizer treatments. The RNP in the form of DAP and UREA fertilizers resulted in significantly lower potato tuber yields than either sole FYM or integrated FYM and mineral fertilizers. Potato plants grown in soils amended with sole blended fertilizer or integrated FYM and mineral fertilizers increased fresh tuber yield by more than $100 \%$ to the control. In general, it can be concluded that the RNP and blended fertilizers alone and their combination with FYM have superior economic yield responses over control. However, the RNP fertilizer resulted in significantly lower marketable yield than either the blended fertilizer or the integrated farmyard manure and mineral fertilizer. Therefore, smallholder potato producers can benefit more if they apply recommended dose of NP fertilizer in combination with FYM depending on their accessibility and ease of applications. In the mixed crop-livestock farming systems where cattle manure could be abundantly available, smallholder farmers should be encouraged to widely utilize FYM together with mineral 
fertilizers to amend the inherently poor and very acidic soils. Soil acidity being one of the major challenges for smallholder farmers in Africa, further studies are required to examine the short-term and long-term effects of application of sole blended mineral fertilizers and integrated applications of organic and mineral fertilizers in improving the productivity of acidic soils.

\section{Acknowledgements}

The authors would like to thank the Global Affairs Canada for the financial support of this study through the Embassy of Canada in Addis Ababa. The Livestock and Irrigation Value Chains for Ethiopian Smallholders (LIVES) project of the International Livestock Research Institute (ILRI) is gratefully acknowledged for supporting the research. The Authors are also thankful to the smallholder farmers who voluntarily availed their lands for the experiments. Hawassa University and the Southern Agricultural Research Institute are thanked for their support.

\section{Conflict of interests}

The authors declare that there is no conflict of interests regarding the publication of this paper.

\section{References}

Ahmad, S., Dagar, J. C., \& Mani, D. (2014). Impact of farm yard manure and potassium interactions on potato yield cultivated on moderate saline soils. J. So. Sal. Wat. Qual., 6, 59-63.

Alemayehu, K., Sheleme, B., \& Schoenau, J. (2017). Fractionation and availability of phosphorus in acidic soils of Hagereselam, southern Ethiopia under different rates of lime. Chem. Biol. Technol. Agric., 4, 1-7.

ATA (Agricultural Transformation Agency). (2014). Transforming agriculture in Ethiopia. Annual report for 2013/2014. ATA, Addis Ababa. (pp. 58-60).

ATA (Agricultural Transformation Agency). (2016). Soil fertility status and fertilizer recommendation atlas of the Southern Nations Nationalities and Peoples' Regional State, Ethiopia, by Ministry of Agriculture and Natural Resources and Agricultural Transformation Agency. Addis Ababa, Ethiopia. (pp. 1-9).

Berhanu, G., Samson, J., Hoekstra, D., \& Ponniah, A. (2012). A guide to market-oriented extension services with special reference to Ethiopia. IPMS (Improving Productivity and Market Success) of Ethiopian Farmers Project. ILRI, Nairobi, 59-68.

Birch, P. R. J., Bryan, G., Fenton, B., Gilroy, E. M., Hein, I., Jones, J. T., Prashar, A., Taylor, M. A., Torrance, L., \& Toth, I. K. (2012). Crops that feed the world 8: Potato: Are the trends of increased global production sustainable? Food Security, 4(4), 477-508.

Bradshaw, J. E., \& Bonierbale, M. (2010). Potato. In J. E. Bradshaw (Ed.), Root and Tuber Crops, Handbook of plant breeding (pp. 1-52). Springer, New York Dordrecht Heidelberg, London.

CIMMYT. (1988). From agronomic data to farmer recommendations: An economic training manuals (pp. 1-79). Completely revised edition. CIMMYT, Mexico.

CSA (Central Statistical Authority). (2016). Agricultural sample survey 2015/16 (2008 E.C) volume V. Report on area, production and farm management practice of Belg season crops for private peasant holdings. CSA, Addis Ababa, Statistical bulletin, 578, 18-19.

Das, S. K., Banerjee, H., Chakraborty, A., \& Sarkar, A. (2015). Production potential of newly released potato (Solanum tuberosum 1.) cultivars under different nitrogen levels. S. J. Agri., 13, 121-130.

Druilhe, Z., \& Barreiro-Hurlé, J. (2012). Fertilizer subsidies in sub-Saharan Africa. FAO, Rome, ESA Working paper No. 12-04.

Duflo, E., Kremer, M., \& Robinson, J. (2008). How High Are Rates of Return to Fertilizer? Evidence from Field Experiments in Kenya. American Economic Review, 98, 482-488.

El-Khider, A. (2003). Response of potato (Solanum tuberosum L.) to different forms and levels of Urea Fertilizer: $M S c$. Thesis (Agric.), University of Khartoum, Khartoum.

Ephrem, G. (2015). Disease management practices on potato (Solanum tuberosum L.) in Ethiopia. W. J. Agr. Res., $3,34-42$.

Estefan, G., Sommer, R., \& Ryan, J. (2013). Methods of soil, plant, and water analysis: A manual for the West Asia and North Africa region (3rd ed.). International Center for Agricultural Research in the Dry Areas (ICARDA). 
Ezzat, A. E.-B. S., El-Awady, A. A., \& Ahmed, H. M. I. (2011). Improving Nitrogen Utilization Efficiency by Potato (Solanum tuberosum L.). Nature and Science, 9, 34-42.

Fahmy, S. H., Sharifi, M., \& Hann, S. (2008). Pulp Fiber Residue and Supplemental Irrigation on Yield and Nutrient Uptake of Potato. Journal of Plant Nutrition, 31, 716-730.

FAO, \& IFA. (2000). Fertilizers and Their Use: A Pocket Guide for Extension Officers. Fourth Edition: FAO, International Fertilizer Industry Association, Rome.

FAO. (2015). In R. Romeo, A. Vita, S. Manuelli, E. Zanini, M. Freppaz, \& S. Stanchi (Eds.), Understanding Mountain Soils: A contribution from mountain areas to the International Year of Soils. Rome, Italy. Retrieved from http://www.mountainpartnership.org

FAOSTAT. (2016). Food and Agriculture Organization (FAO) of the United Nations. Retrieved from http://www.fao.org/faostat/en/\#data/QC

Gee, G. W., \& Bauder, J. W. (1986). Particle-size analysis. In A. Klute (Ed.), Methods of Soil Analysis (Part 1. Agron. Monogr. 9. 2nd ed., pp. 383-411). ASA and SSSA, Madison, WI.

Gildemacher, P. R., Kaguongo, W., Ortiz, O., Tesfaye, A., Woldegiorgis, G., Wagoire, W. W., Kakuhenzire, R., Kinyae, P. M., Nyongesa, M., Struik, P. S., \& Leeuwis, C. (2009). Improving Potato Production in Kenya, Uganda and Ethiopia: A System Diagnosis. Potato Research, 52, 173-205.

Guo, J. H., Liu, X. J., Zhang, Y., Shen, J. L., Han, W. X., Zhang, W. F., Christie, P., Goulding, K. W. T., Vitousek, P. M., \& Zhang, F. S. (2010). Significant Acidification in Major Chinese Croplands. Science, 327, 1008-1010.

Hao, X., Cho, C. M., Racz, G. J., \& Chang, C. (2002). Chemical retardation of phosphate diffusion in an acid soil as affected by liming. Nutr. Cycl. Agroecosys., 64, 213-224.

Havlin, J. L., Beaton, J. D., Tisdale, S. L., \& Nilson, W. L. (1999). Soil fertility and fertilizer: An introduction to nutrient management. Prentice Hall Upper Saddle River, New Jersey.

Haynes, R. J., \& Mokolobate, M. S. (2001). Amelioration of Al toxicity and P deficiency in acid soils by additions of organic residues: A critical review of the phenomenon and the mechanisms involved. Nutrient Cycling in Agroecosystems, 59, 47-63.

Hazelton, P., \& Murphy, B. (2007). Interpreting soil test results what do all the numbers mean? Csiro Publishing, Australia.

Hirpa, A., Meuwissen, M. P. M., Lommen, W. J. M., Lansink, A. G. J. M., Tsegaye, A., \& Struik, P. C. (2016). Improving seed potato quality in Ethiopia: A value chain perspective. In J. Bijman, \& V. Bitzer (Eds.), Quality and innovation in food chains (pp. 101-117). Wageningen Academic Publishers, Wageningen.

Jones, C., \& Jacobsen, J. (2001). Plant nutrition and soil fertility: Nutrient Management Module, (2), 7-8.

Kavvadias, V., Paschalidis, C., Akrivos, G., \& Petropoulos, D. (2012). Nitrogen and potassium fertilization responses of potato (Solanum tuberosum). Communications in Soil Science and Plant Analysis, 43, 176-189.

Kefyalew, K. (2010). Fertilizer consumption and agricultural productivity in Ethiopia. Ethiopian Development Research Institute, Addis Ababa, 20-21.

Kinyua, Z. M., Smith, J. J., Lung'aho, C., Olanya, M., \& Priou, S. (2001). On-farm successes and challenges of producing bacterial wilt-free tubers in seed plots in Kenya. African Crop Science Journal, 9, 279-286.

Kirsten, A. (2014). The Agronomy Guide: Penn State College of Agricultural Sciences (pp. 41-58).

Kumar, M., Baishaya, L. K., Ghosh, D. C., Gupta, V. K., Dubey, S. K., Das, A., \& Patel, D. P. (2012). Productivity and soil health of potato (Solanum tuberosum L.) field as influenced by organic manures, inorganic fertilizers and biofertilizers under high altitudes of eastern Himalayas. J. Agri. Sc., 4, 223-234.

Landon, J. R. (2013). Booker tropical soil manual: A handbook for soil survey and agricultural land evaluation in the tropical and subtropical, Taylor and Francis group (pp. 106-130). New York, USA.

Lemaga, B., Siriri, D., \& Ebanyat, P. (2001). Effect of soil amendments on bacterial wilt incidence and yield of potatoes in southwestern Uganda. African Crop Science Journal, 9, 267-278.

Liu, Y., Villalba, G., Ayres, R. U., \& Schroder, H. (2008). Global Phosphorus Flows and Environmental Impacts from a Consumption Perspective. J. Indust. Ecol., 12, 229-247. 
Mekasha, Y., Biazin, B., Tegegn, A., Shewage, T., Zewdie, T., \& Tera, A. (2015). Spatio-temporal dynamics of natural grazing lands and livestock holding in Sidama highlands of Southern Ethiopia: Implications for sustainable grazing land development. J. Agr. Eng. Biot., 3, 109-119.

Mengel, K., \& Kirkby, E. A. (1987). Principles of plant nutrition (pp. 87-90). International Potash Institute, Berne.

Mesfin, A. (2009). Social assessment and fertilizer support project. Ministry of Agricultural and Rural Development, Addis Ababa, 5.

Motsara, M. R., \& Roy, R. N. (2008). Guide to laboratory establishment for plant nutrient analysis: FAO Fertilizer and Plant Nutrition bulletin 19 (pp 40-60). FAO, Rome.

Olanya, O. M., Adipala, E., Hakiza, J. J., Kedera, J. C., Ojiambo, P., Mukalazi, J. M., Forbes, G., \& Nelson, R. (2001). Epidemiology and population dynamics of Phytophthora infestans in Sub-Saharan Africa: Progress and constraints. African Crop Science Journal, 9, 185-194.

Paul, G. (2016). The impact of coffee-based agroforestry on the hydrology of the upper Genale River basin, Sidama Zone, Ethiopia (pp. 1-29). MSc thesis, Utrecht University, the Netherlands.

Place, F., Barrett, C. B., Freeman, H. A., Ramisch, J. J., \& Vanlauwe, B. (2003). Prospects for integrated soil fertility management using organic and inorganic inputs: Evidence from smallholder African agricultural systems. Food Policy, 28, 365-378.

Rengel, Z. (2003). Handbook of soil acidity. University of Western Australia Perth. Marcel Dekker Inc., New York, USA, ISBN: 0824708903.

Sahlemedhin, S., \& Taye, B. (2000). Procedures for soil and plant analysis. Technical Paper No.74. Addis Ababa, 13-49.

SAS.(1997). SAS Institute Inc., Cary. NC. USA.

Schröder, J. J., Smit, A. L., Cordell, D., \& Rosemarin, A. (2011). Improved phosphorus use efficiency in agriculture: A key requirement for its sustainable use. Chemosphere, 84, 822-831.

Shen, J., Yuan, L., Zhang, J., Li, H., Bai, Z., Chen, X., Zhang, W., \& Zhang, F. (2011). Phosphorus Dynamics: From Soil to Plant. Plant Physiology Preview. American Society of Plant Biologists, 1-29.

Sommer, S. G., Schjoerring, J. K., \& Denmead, O. T. (2004). Ammonia emission from mineral fertilizers and fertilized crops. Advances in Agronomy, 82, 557-622.

Takeda, M., Nakamoto, T., Miyazawa, K., Murayama, T., \& Okada, K. (2009). Phosphorus availability and soil biological activity in an Andosol under compost application and winter cover cropping. Applied Soil Ecol., 42, 86-95.

Tantowijoyo, W., \& Fliert, E. (2006). All about potatoes: An ecological guide to potato integrated crop management. International Potato Center (CIP) \& FAO Regional Vegetable IPM Program in South and Southeast Asia, 5-6.

Tesfaye, B. (2012). Effect of integrated use of cattle manure and inorganic fertilizers on tuber yield of potato in Ethiopia. J. So. Sci. Pl. Nut., 12, 257-265.

von Uexku", H. R., \& Mutert, E. (1995.) Global extent, development and economic impact of acid soils. In R. A. Date, N. J. Grundon, G. E. Raymet, \& M. E. Probert (Eds.), Plant-Soil Interactions at Low pH: Principles and Management (pp. 5-19). Dordrecht, The Netherlands: Kluwer Academic Publishers.

Walkley, A., \& Black, C. B. (1934). An examination of Degtjareff method for determining soil organic matter and proposed modification of the chromic acid titration method. Soil Sci., 37, 29-38.

Zheng, S. J. (2010). Crop production on acidic soils: overcoming aluminum toxicity and phosphorus deficiency. Annals of Botany 106, 183-184.

\section{Copyrights}

Copyright for this article is retained by the author(s), with first publication rights granted to the journal.

This is an open-access article distributed under the terms and conditions of the Creative Commons Attribution license (http://creativecommons.org/licenses/by/4.0/). 